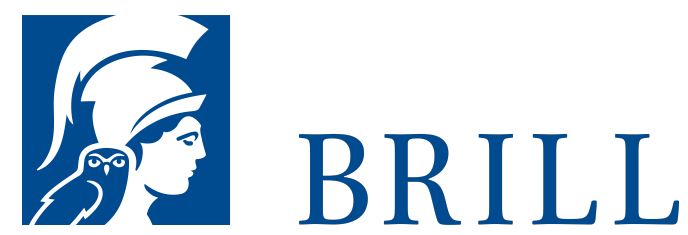

\title{
Die unkonventionelle Geldpolitik der EZB
}

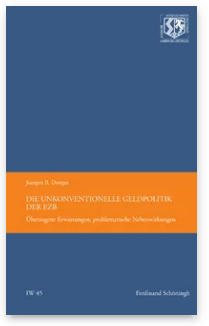

Die monet Ãaren Bedingungen fã $1 / 4$ r die wirtschaftliche AktivitÃăt der IndustrielÃander werden seit der Weltfinanzund wirtschaftskrise durch eine beispiellose ultralockere Geldpolitik der Notenbanken geprãagt. Neben der Senkung der Leitzinsen bis nahe null schlug allenthalben die Stunde der â€žkreativenâ€œ Geldpolitik. Die EZB legte zahlreiche Programme zur Versorgung des Bankensystems mit umfangreicher LiquiditÃăt zu sehr g $\tilde{A}^{1}$ /4nstigen Bedingungen auf. Hinzugekommen ist der milliardenschwere Ankauf von Staatsanleihen. Die Lenkungsfunktion des Zinsmechanismus wurde auÃ Ÿer Kraft gesetzt. Aus der Analyse ergibt sich ein fragw $\tilde{A} 1 / 4$ rdiges Kosten-Nutzen-VerhÃ Empfehlung einer baldigen Kehrtwende in der europÃaischen Geldpolitik. 
For more information see brill.com

Order information: Order online at brill.com +44330 333 0049 | customerservices@brill.com Submission information: brill.com/authors

Titles published by Brill | Fink, Brill | mentis or Brill | Schöningh: +49(o)715413279216| brill@brocom.de 